\title{
THE EFFECT OF HIGH-SPEED GRINDING TECHNOLOGY ON THE PROPERTIES OF FLY ASH
}

\author{
VPLIV TEHNOLOGIJE HITREGA MLETJA NA LASTNOSTI \\ LETEČEGA PEPELA
}

\author{
Karel Dvořák, Iveta Hájková \\ Brno University of Technology, Faculty of Civil Engineering, Veveř́ 331/95, 60200 Brno, Czech Republic \\ dvorak.k@fce.vutbr.cz \\ Prejem rokopisa - received: 2015-06-23; sprejem za objavo - accepted for publication: 2015-09-21
}

doi:10.17222/mit.2015.127

\begin{abstract}
The aim of this work was to observe the impact of the milling technique employed by the DESI 11 disintegrator on the properties of fly ash. This type of mill is a high-speed pin mill with two counter rotors. The device selected for study allows the use of rotors with different working tools. In this case, two types of rotors were selected, identified as BR-AR and OR rotors. The OR rotor has cylindrical teeth, while the teeth on the AR-BR rotor can be described as rhomboidal. The fly ash was ground by $1,2,3,5$, and 10 passes through the mill. The Blaine specific surface area, particle size and particle size distribution were measured for each sample. The pozzolanic activity was also determined via a modified Chapelle test, and its influence on the shape of the grains was assessed by SEM. The results were compared together and with the original fly ash. There was a steep increase in the specific surface area and pozzolanic activity after the first pass through the mill. The second pass of ash through the mill did not increase the specific surface area due to strong aggregation, which gradually changes into agglomeration. However, the pozzolanic activity still increased during the aggregation phase. This phenomenon was clearly observable for both types of selected rotors. Based on the results, we can say that in the case of fly ash, a high-speed disintegrator can be a promising means of improving its properties via grinding and mechanical activation.

Keywords: high speed grinding, fly ash, pozzolanic activity
\end{abstract}

Namen dela je opazovati posledice uporabljene tehnike mletja, v DESI 11 mlinu, na lastnosti letečega pepela. To je mlin z veliko hitrostjo, z dvema nasprotnima rotorjema. Naprava, izbrana za študij, omogoča uporabo rotorjev z različnimi orodji. V tem primeru sta bila izbrana dva različna rotorja, označena kot AR-BR in OR rotor. OR rotor ima cilindričen zob, medtem ko je zob na AR-BR rotorju označen kot romboidalen. Leteči pepel je bil zmlet z 1, 2, 3, 5 in 10 prehodi skozi mlin. Za vsak vzorec so bile izmerjene Blainova specifična velikost površine ter velikost in razporeditev delcev. Pucolanska aktivnost je bila določena z modificiranim Chapelle testom. Vpliv na obliko zrn je bil določen s SEM. Rezultati so bili primerjani z originalnim letečim pepelom. Po prvem prehodu skozi mlin se je skokovito povečala specifična površina in pucolanska aktivnost. Drugi prehod pepela skozi mlin ni povečal specifične površine zaradi močne agregacije, ki se je postopoma spremenila $\mathrm{v}$ aglomeracijo. Vseeno pa je pucolanska aktivnost še naraščala med fazo agregacije. Ta pojav je bil jasno opažen pri obeh vrstah rotorjev. Na osnovi teh rezultatov lahko rečemo, da je v primeru letečega pepela dezintegrator $\mathrm{z}$ veliko hitrostjo obetajoče sredstvo, da $\mathrm{z}$ mletjem in mehansko aktivacijo izboljšamo njegove lastnosti.

Ključne besede: mletje z veliko hitrostjo, leteči pepel, pucolanska aktivnost

\section{INTRODUCTION}

One of the trends in the area of milling that have been intensively examined recently is high-energy milling (HEM). With HEM there are certain phenomena that have not been observed in conventional grinding. These phenomena can be summarized by the term mechanochemical activation. ${ }^{1}$ The idea of mechanochemical activation is that an increase occurs in the value of the internal energy, consequently increasing the enthalpy and the formation of so-called active surfaces on the newly formed grains. To increase the level of enthalpy, it is not only necessary to supply a large amount of mechanical energy, but it is also important how that energy is transmitted to the material. Only if the material is capable of absorbing the energy can the internal structure of the substance be destabilized and new active surfaces be developed. ${ }^{2}$ The effects of mechanical activation have been described for model materials such as dolomite ${ }^{3}$ or clay minerals, ${ }^{4-6}$ or, for example, for silica. ${ }^{7}$ In the field of grinding and mechanical activation, research is fo- cused on monitoring changes in the crystal structure and amorphization, ${ }^{6,8}$ changes in the granularity and the aggregation and agglomeration of particles, 9,10 and changes in surface properties, especially the specific surface area and the zeta potential. ${ }^{4,8}$ One type of HEM is high-speed grinding (HSG). HSG involves supplying large amounts of energy using very short and intense power pulses. The amount of energy that is effectively transferred to the material is higher in the case of HSG than with conventional grinding in mills with the same power input. One of the types of mills suitable for HSG is a high-speed pin mill with two counter-rotating rotors, known as a disintegrator. ${ }^{11}$ This type of mill is particularly suitable for the grinding and activation of fine powder materials. ${ }^{12}$ The material is refined by very intensive changes in the mechanical stress, which take place at a very high frequency. Another advantage is the variety of working tools that can be employed to affect the grinding process. ${ }^{13}$ The disadvantage of this type of milling in the case of silicates is the significant electro- 
static charging of the particles and their easy and quick aggregation. ${ }^{1}$ One of the important silicate materials that are widely used in the construction industry is ash, various kinds of which exist. A number of authors describe the utilization and effects of pin mills on the physical and mechanical properties of both fluidized bed ashes ${ }^{14,15}$ and ashes based on $\mathrm{SiO}_{2} \cdot{ }^{16}$ In the case of fly ash, during traditional milling and even during HEM there is not only an increase in the specific surface area, but also an improvement in the reactivity. Different authors use a wide spectrum of methods for the assessment of reactivity, though it is typically done by FTIR and calorimetric methods during the hydration of cement pastes containing fly ash. ${ }^{17,18}$ Increases in the reactivity are commonly achieved via the refinement of large porous particles of ash, i.e., plerospheres, which is relatively easy to do. The refinement of cenospheres is more difficult, and requires more grinding work, but leads to a further increase in the pozzolanic activity of the fly ash. ${ }^{19}$ The particles remain in the chamber of the high-speed disintegrator for only a few seconds, which is because of the principle by which the pin mill operates. Repeating the passing of the material through the mill is the only effective way of extending the milling time. However, in the case of fly ash it entails the risk of grain agglomeration. The aim of this work was to describe and assess the effect of a HSG disintegrator's milling technique on the fly ash's properties, especially its pozzolanic properties, grain size, grain morphology and specific surface area.

\section{MATERIALS AND METHODS}

TEKO fly ash was used for monitoring the impact of the milling technique in question on the material properties. The fly ash was analyzed before the milling began, with its chemical composition being determined by traditional chemical analyses. The density was determined using a Micromeritics AccuPyc II 1340 automatic pycnometer. For the measurement of the Blaine specific surface area, a PC-Blaine-Star automatic device was used with a measurement cell capacity of $7.95 \mathrm{~cm}^{3}$. The determination was performed three times to eliminate errors, and the resultant value was the average of these determinations. Milling of the samples was carried out in a DESI 11 disintegrator, which is a high-speed pin mill with two counter-rotating rotors. The total installed power of this mill is $4.1 \mathrm{~kW}$. The rotors' rotation frequency is up to $200 \mathrm{~Hz}$, and the maximum speed of impact is $240 \mathrm{~ms}^{-1}$. The material is dispensed by a continuous feeder and enters the grinding chamber through the middle of the left rotor. To assess the effect of the selected milling technique, two rotor types were used for comparative purposes, i.e., types AR-BR and OR. The rotors were designed and manufactured by FF Service Ltd. Both types have two rows of teeth on the left-hand rotor and three rows of teeth on the right-hand rotor. The OR rotor has cylindrical teeth, while the shape of the teeth on the AR-BR rotor can be described as rhom- boidal. With this kind of rotor, the tilt direction of the leading edge against the flow of material on the left-hand rotor is always opposite to that of the right-hand rotor. A continuous feeder was used for dosing the fly ash into the mill. The ash was always fed in at a dose of $0.5 \mathrm{~kg}$ and milled at the maximum $\mathrm{Hz}$. The time required for all the material to pass through the mill was $180 \mathrm{~s}$. The samples for both rotor variants were prepared for 1, 2, 3, 5 and 10 passes through the mill. Grinding was performed under standard laboratory conditions, at $22{ }^{\circ} \mathrm{C}$ and with a relative humidity of $56 \%$. Between the steps of grinding, the mill was cooled by an air stream so that the temperature of the working chamber did not exceed $70{ }^{\circ} \mathrm{C}$. The Blaine specific surface area was determined for all the samples. All the fly ash samples, including the control sample, were subjected to particle size distribution measurements by laser granulometry. This analysis was performed on a Malvern Mastersizer 2000 with a Hydro $2000 \mathrm{G}$ wet dispergation unit; 2-isopropanol was used as a dispersant. The effect of the milling technique on the morphology of the grains was observed and assessed by electron microscopy (SEM). A Tescan MIRA 3 XMU SEM with a secondary electron detector was used. The Chapelle test method ${ }^{20}$ was used to determine the pozzolanic activity This test was done on the control sample of fly ash and the samples ground via one, three, and ten passes. The method was adapted for the needs of the experiment. The modified Chapelle test consists of allowing pozzolan and freshly annealed $\mathrm{CaO}$ to react together in an aquatic environment at $93{ }^{\circ} \mathrm{C}$ for $24 \mathrm{~h}$. The reaction takes place in a tightly closed stainless-steel vessel and the suspension is stirred with an electromagnetic stirrer. The result is expressed as the amount of $\mathrm{Ca}(\mathrm{OH})_{2}$ bound in mg per $1 \mathrm{~g}$ of pozzolan. The results were compared to each other and with those from the control sample of fly ash.

\section{RESULTS}

The results for the chemical composition of the control TEKO fly ash are shown in Table 1. Only selected oxides and loss on ignition are listed in the table.

Table 1: The chemical composition of the fly ash

Tabela 1: Kemijska sestava letečega pepela

\begin{tabular}{|c|c|c|c|c|c|c|c|}
\hline $\begin{array}{c}\text { Compo- } \\
\text { nents }\end{array}$ & $\mathrm{SiO}_{2}$ & $\mathrm{Al}_{2} \mathrm{O}_{3}$ & $\mathrm{Fe}_{2} \mathrm{O}_{3}$ & $\mathrm{CaO}$ & $\mathrm{SO}_{3}$ & $\begin{array}{c}\text { Loss on } \\
\text { ign. }\end{array}$ & Others \\
\hline $\begin{array}{c}\text { Content \% } \\
\text { per mass }\end{array}$ & 51.8 & 18.1 & 9.1 & 6.7 & 0.8 & 6 & 7.5 \\
\hline
\end{tabular}

The specific surface area and density are then presented in Table 2.

Table 2: Density and specific surface area of the TEKO fly ash Tabela 2: Gostota in specifična površina TEKO letečega pepela

\begin{tabular}{|c|c|}
\hline Density $\left(\mathrm{kg} / \mathrm{m}^{3}\right)$ & 2423 \\
\hline Specific surface area $\left(\mathrm{m}^{2} / \mathrm{kg}\right)$ & 494 \\
\hline
\end{tabular}


The chemical and physical properties are typical for conventional siliceous ash.

The specific surface area values were determined from the samples ground via the selected operating mode for both types of rotors immediately after passing through the mill. The specific surface area results for both types of rotors are shown in Figure 1.

After the first pass of the samples through the mill, a significant increase in the specific surface area is apparent in both cases. However, after the second pass through a significant decrease in the specific surface area can be seen. The decrease in specific surface area in the initial stages was greater in the case of the AR-BR rotors. Each additional pass through the mill led to a further reduction in the surface area. However, after ten cycles, the sample milled by the OR rotor had a lower specific surface area than the sample milled by the AR-BR rotor.

The granulometry of the control fly ash and of all the ground samples was analyzed by laser granulometry. Selected laser granulometry results for both types of rotor are shown in Figures $\mathbf{2 a}$ and $\mathbf{2 b}$.

The dependence of the grain size $d(0.1), d(0.5)$ and $d(0.9)$ on the number of passes of the material through the mill is summarized in Table $\mathbf{3}$ in order to facilitate a comparison of the impact of the milling technique on the course of the grinding.

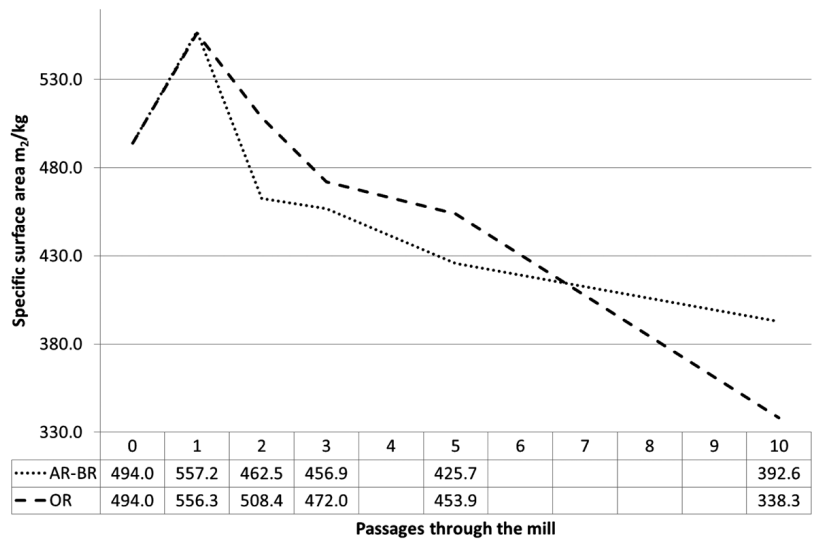

Figure 1: Specific surface area for all the samples Slika 1: Specifična površina pri vseh vzorcih
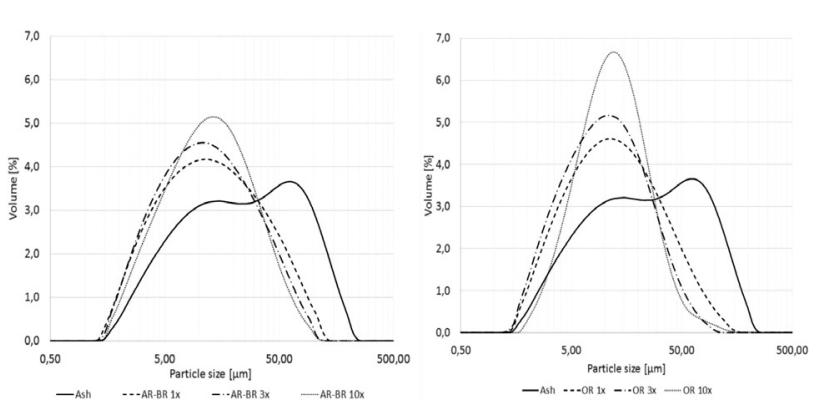

Figure 2: Particle size distribution: a) AR-BR and b) OR Slika 2: Razporeditev velikosti delcev: a) AR-BR in b) OR
Table 3: The dependence of the grain size $d(0.1), d(0.5)$ and $d(0.9)$ on the number of passes of the material through the mill

Tabela 3: Odvisnost velikosti zrn $d(0,1), d(0,5)$ in $d(0,9)$ od števila prehodov materiala skozi mlin

\begin{tabular}{|c|c|c|c|c|c|c|c|}
\hline & \multicolumn{7}{|c|}{ Number of passes through the mill } \\
\hline & $d / \mu \mathrm{m}$ & 0 & 1 & 2 & 3 & 5 & 10 \\
\hline \multirow{4}{*}{ AR-BR } & 0.1 & 4.90 & 3.52 & 3.66 & 3.53 & 3.99 & 3.99 \\
\cline { 2 - 9 } & 0.5 & 25.60 & 13.19 & 13.19 & 12.02 & 12.15 & 12.99 \\
\cline { 2 - 8 } & 0.9 & 108.083 & 52.87 & 47.80 & 43.86 & 37.57 & 40.08 \\
\hline \multirow{4}{*}{ OR } & 0.1 & 4.90 & 3.68 & 3.47 & 3.39 & 4.27 & 4.85 \\
\cline { 2 - 8 } & $0.5)$ & 25.60 & 12.56 & 11.72 & 10.61 & 11.40 & 12.39 \\
\cline { 2 - 8 } & 0.9 & 108.083 & 46.59 & 38.90 & 32.45 & 33.01 & 30.91 \\
\hline
\end{tabular}

In both cases, after the first pass there was a significant reduction in the proportion of coarse particles, with each additional grinding causing a further decline in the amount present. However, at the same time, there was also a decrease in the proportion of ultra-fine parti-
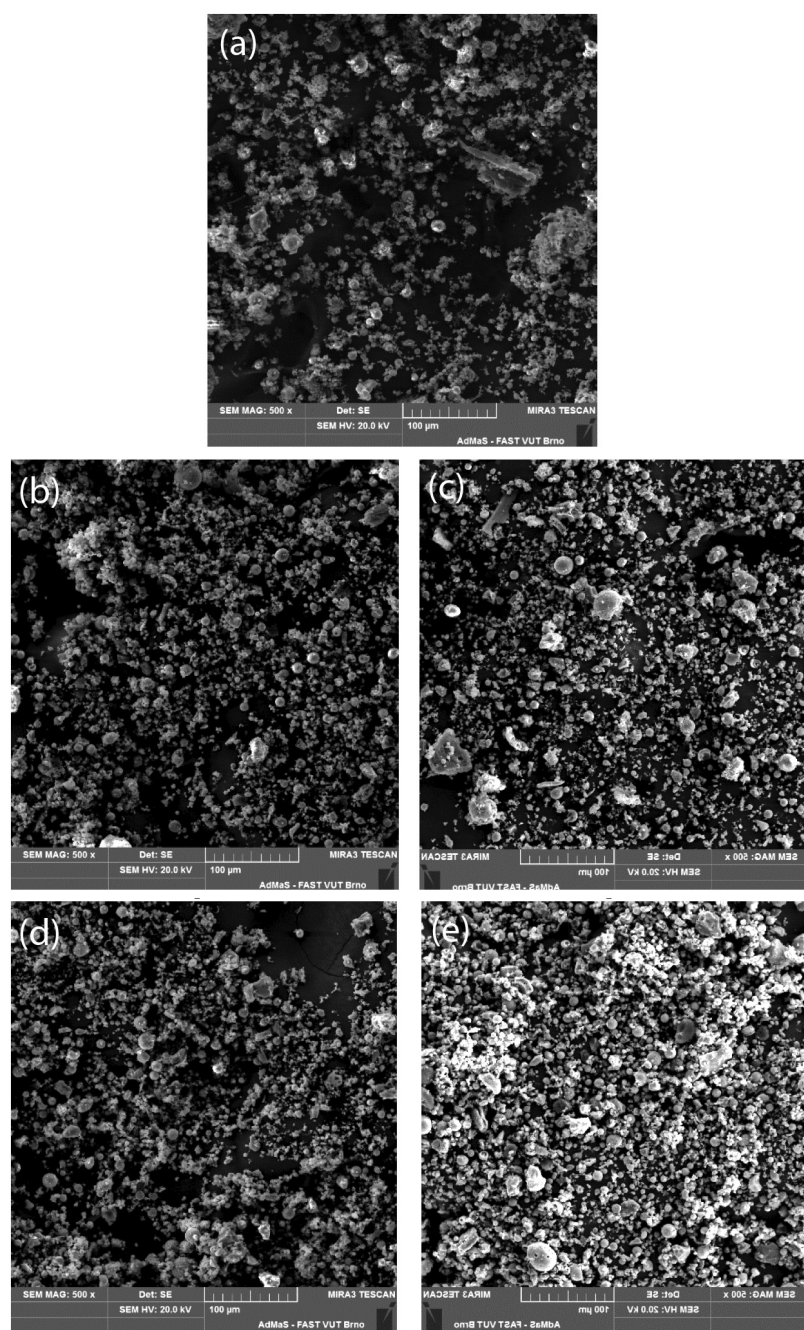

Figure 3: a) The morphology of the control fly ash, b) 1 pass, AR-BR rotors, c) 1 pass, OR rotors, d) 10 pass, AR-BR rotors and e) 10 pass, OR rotors

Slika 3: a) Morfologija kontrolnega letečega pepela, b) 1 prehod, AR-BR rotorji, c) 1 prehod, OR rotorji, d) 10 prehod, AR-BR rotorji in e) 10 prehod, OR rotorji 


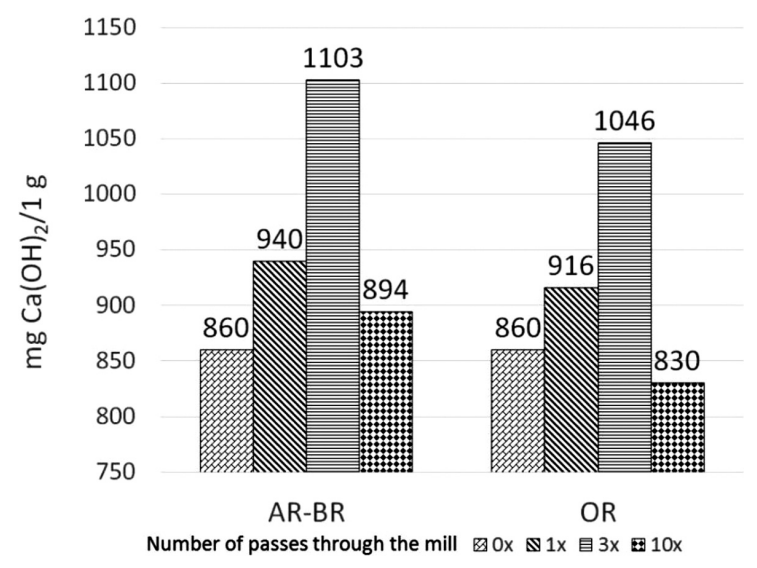

Figure 4: The impact of the technology of grinding on the pozzolanic activity

Slika 4: Vpliv tehnologije mletja na pucolansko aktivnost

cles. The distribution curves after 10 passes were significantly narrower. This phenomenon is more significant in the case of the OR rotor. The results of the effect of the rotors and the number of passes on the morphology of the grains after one and ten passes of fly ash through the mill are illustrated in Figures 3a to $\mathbf{3 e}$.

The SEM analysis shows that a clearly visible refining process is occurring, along with the subsequent agglomeration of particles. This effect is more distinctive in the case of the OR rotors.

Based on the evaluation of the specific surface area, samples were selected after one, three and ten passes through the mill for the purpose of determining the pozzolanic activity. The results of this determination are shown in Figure 4.

In both cases the first significant increase in evident pozzolanic activity did not occur until the third pass. A significant decrease occurred after the tenth cycle, this being mainly the case for the OR rotors.

\section{DISCUSSION}

A chemical composition with a high content of $\mathrm{SiO}_{2}$ and a low content of $\mathrm{SO}_{3}$ is typical for conventional siliceous ash. Morphologically, it is a mixture of spherical cenospheres and porous plerospheres, as is apparent from the SEM image. Its specific surface area of 494 $\mathrm{m}^{2} / \mathrm{kg}$ is relatively high, which corresponds to the higher pozzolanic activity of fly ash at $860 \mathrm{mg}$ of $\mathrm{Ca}(\mathrm{OH})_{2} / 1 \mathrm{~g}$, as determined by the modified Chapelle test. The pozzolanic activity of fly ash tested by this method usually ranges from 700 to $850 \mathrm{mg} \mathrm{Ca}(\mathrm{OH})_{2} / 1 \mathrm{~g}^{21}$ This fly ash can therefore be rated as reactive. In the case of both types of rotor, a step increase in the specific surface area occurred after the first pass of the ash through the mill. The specific surface area increased by about $60 \mathrm{~m}^{2} / \mathrm{kg}$ to a final $557 \mathrm{~m}^{2} / \mathrm{kg}$ in both cases. The growth in specific surface area is associated with a decrease in the grain sizes $d(0.1), d(0.5)$ and $d(0.9)$, which is clearly visible from the particle size distribution curves in Figures 2a and $\mathbf{2 b}$. As regards the rotors, the AR-BR curve is clearly wider than that for the OR type. At this stage, especially large, soft and porous plerospheres are milled very intensively, as evidenced by the SEM images above. However, the amount of pozzolanic activity is already different at this stage of the milling process. Fly ash ground on the AR-BR rotors showed pozzolanic activity that was $24 \mathrm{mg}$ of $\mathrm{Ca}(\mathrm{OH})_{2} / 1 \mathrm{~g}$ higher for the same specific surface area than ash ground on the OR rotors. The results correspond well with the particle size distribution curves when the AR-BR sample contains more ultra-fine particles. A sharp decline in the specific surface area can be observed after the second and third passes. This phenomenon can be explained as being the result of the beginning of the aggregation process due to electrostatic forces. The lower decrease in the specific surface area value in the case of the OR rotors than for the AR-BR type can be explained by the cylindrical shape of the teeth on the OR rotors. The friction surface over which the particles roll is smaller with this tooth shape. The charging of the particles, which leads to aggregation, is thus smaller. The aggregation process can be clearly observed on the granulometric curves, which become narrower. However, in both cases, the pozzolanic activity increased significantly. This phenomenon can be explained as being just due to the formation of aggregates, which are only loosely bound together by electrostatic forces. Because the Chapelle test takes place in an aquatic environment, loosely bonded aggregates can easily disintegrate and the fine particles can react with the calcium ions very swiftly and easily. In the case of the AR-BR rotors, the increase in pozzolanic activity is significantly higher than in the case of the OR rotors. A possible explanation for this abnormality is simply that the AR-BR rotor teeth have a larger contact surface. They thus charge particles and accelerate the formation of aggregates more than the cylindrical teeth of the OR rotors, but may also create more defects on the surfaces of the fly ash particles, causing the particles to become more reactive. Between the third and the tenth passes, a gradual decline in specific surface area can be observed. The particle distribution curves become narrower and there is a significant increase in grain size $d(0.1)$. At this point the aggregation phase has already changed to the stage of agglomeration, where the particles are bound by chemical bonds. ${ }^{1}$ This confirms the results of the pozzolanic activity determination, and the SEM images. The specific surface area and pozzolanic activity results achieved by the OR rotors after ten passes are significantly worse than in the case of the AR-BR rotors. Because most of the grinding work in the phase of agglomeration is just consumed in the breakage of new agglomerates, the results indicate the AR-BR rotors have a higher efficiency compared to the OR rotors.

\section{CONCLUSION}

High-speed grinding in a high-speed disintegrator is very effective during the first pass of fly ash through the 
mill, when there is a step increase in the specific surface area, and related pozzolanic activity. During the first pass there is no aggregation or agglomeration of the grains. Fly ash can thus be easily homogenized with the other components of the cement composite, and its properties can be improved at the same time. The disadvantage of this type of mill is the process of rapid aggregation and subsequent agglomeration, which makes it impossible to achieve a higher specific surface area. However, this phenomenon can be eliminated by adding grinding aids or using particle separators, for example. We can conclude based on all the achieved results that the use of the AR-BR rotor with rhomboid-shaped teeth for the grinding of fly ash is more advantageous in the case of a HSG disintegrator than using the OR rotor with its traditional cylindrical tooth shape. Higher pozzolanic activity was achieved for the same specific surface area. Based on the results, we can say that in the case of fly ash, a highspeed disintegrator can be a promising means of improving its properties via grinding and mechanical activation.

\section{Acknowledgment}

This work was financially supported by project No. LO1408 "AdMaS UP - Advanced Materials, Structures and Technologies", supported by the Ministry of Education, Youth and Sports under "National Sustainability Programme I" and by project No. 15-08755S: "Study of the effects of samples preparation on the final properties of inorganic binders".

\section{REFERENCES}

${ }^{1}$ P. Baláž, Mechanochemistry in Nanoscience and Minerals Engineering, Springer-Verlag, Berlin, Heidelberg 2008

${ }^{2}$ I. A. Massalimov, Materials processing in a disintegrator and their use for the improvement of chemical technologies, the Abstract of doctoral thesis, Ufa 2005, http://www.ogbus.ru/authors/Massalimov/ Massalimov_1.pdf

${ }^{3}$ K. Tkáčková, Mechanical Activation of Minerals, Minerals Engineering, 11 (1991) 4, 185, doi:10.1016/0892-6875(91)90035-T

${ }^{4}$ N. Vdovic, I. Jurina, S. D. Skapin, I. Sondi, The surface properties of clay minerals modified by intensive dry milling-revisited, Applied Clay Science, 48 (2010) 4, 575-580, doi:10.1016/j.clay.2010.03.006 ${ }^{5}$ F. Garcia, N. L. Bolay, J. L. Trompette, C. Frances, On fragmentation and agglomeration phenomena in an ultrafine wet grinding process: the role of polyelectrolyte additives, International Journal of Mineral
Processing, 74 (2004) 10, S43-S54, doi:10.1016/j.minpro.2004.07. 001

${ }^{6}$ J. Hrachova, P. Komadel, V. S. Fajnor, The effect of mechanical treatment on the structure of montmorillonite, Materials Letters, 61 (2007) 16, 3361-3365, doi:10.1016/j.matlet.2006.11.063

${ }^{7}$ N. Kotake, M. Kuboki, S. Kiya, Y. Kandac, Influence of dry and wet grinding conditions on fineness and shape of particle size distribution of product in a ball mill, Advanced Powder Technology, 22 (2011) 1, 86-92, doi:10.1016/j.apt.2010.03.015

${ }^{8}$ E. C. Sanchez, E. Torres, M. C. Diaz, F. Saito, Effects of grinding of the feldspar in the sintering using a planetary ball mill, Journal of Materials Processing Technology, 152 (2004) 3, 284-290, doi:10.1016/j.jmatprotec.2004.04.367

${ }^{9}$ F. Garcia, N. L. Bolay, C. Frances, Changes of surface and volume properties of calcite during a batch wet grinding process, Chemical Engineering Journal, 85 (2002) 2-3, 177-187, doi:10.1016/S13858947(01)00152-8

${ }^{10}$ C. Knieke, M. Sommer, W. Peukert, Identifying the apparent and true grinding limit, Powder Technology, 195 (2009) 1, 25-30, doi:10.1016/j.powtec.2009.05.007

${ }^{11}$ V. Hanykýř, J. Kutzendörfer, Technologie keramiky, Silis, Prague 2008

${ }^{12} \mathrm{~V}$. V. Boldyrev, Mechanochemistry and mechanical activation of solids, Russian Chemical Reviews, 75 (2006) 3, 177-189, doi:10.1070/RC2006v075n03ABEH001205

${ }^{13}$ B. M. Kipnis, Analysis of prospects for the UDD - technology in the field of polymeric materials, UDD - Technology Abstracts II, (1983), 44-46

${ }^{14} \mathrm{M}$. Faltus, New types of hydraulic binders based on waste materials, $13^{\text {th }}$ International Conference of Research Institute of Building Materials, 2009, 200-208

${ }^{15} \mathrm{M}$. Procházka, The test results of the new hydraulic binder DASTIT as a component of blended cements, $13^{\text {th }}$ International Conference of Research Institute of Building Materials, 2009, 188-194

${ }^{16}$ R. Hela, D. Orsáková, The Mechanical Activation of Fly, Procedia Engineering, 65 (2013), 87-93, doi:10.1016/j.proeng.2013.09.016

${ }^{17}$ S. Kumar, R. Kumar, Mechanical activation of fly ash: Effect on reaction, structure and properties of resulting geopolymer, Ceramics International, 37 (2011) 2, 533-541, doi:10.1016/j.ceramint.2010.09. 038

${ }^{18}$ N. Marjanović, M. Komljenović, Z. Baščarević, V. Nikolić, Improving reactivity of fly ash and properties of ensuing geopolymers through mechanical activation, Construction and Building Materials, 57 (2014), 151-162, doi:10.1016/j.conbuildmat.2014.01.095

${ }^{19} \mathrm{~S}$. Aydin, C. Karatay, B. Baradan, The effect of grinding process on mechanical properties and alkali-silica reaction resistance of fly ash incorporated cement mortars, Powder technology, 197 (2010) 1-2, 68-72, doi:10.1016/j.powtec.2009.08.020

${ }^{20}$ R. Largent, Estimation de l'activité pouzzolanique, Bull Liaison Labo P et Ch, 93 (1978), 61-65

${ }^{21}$ J. Pokorný, M. Pavlíková, E. Navrátilová, P. Rovnaníková, Z. Pavnlík, R. Černý, Application of a-SiO ${ }_{2}$ Rich Additives in Cement Paste, Applied Mechanics and Materials, 749 (2015), 362-367, doi:10.4028/www.scientific.net/AMM.749.362 